University of South Florida

DIGITAL COMMONS

Digital Commons @ University of

@ UNIVERSITY OF SOUTH FLORIDA

South Florida

$1-1-2013$

\title{
2013 Work Plan USF St. Petersburg
}

USF

Follow this and additional works at: https://digitalcommons.usf.edu/usf_accountability_reports

\section{Scholar Commons Citation}

USF, "2013 Work Plan USF St. Petersburg" (2013). USF Accountability Reports. 39.

https://digitalcommons.usf.edu/usf_accountability_reports/39

This Article is brought to you for free and open access by the USF Archives at Digital Commons @ University of South Florida. It has been accepted for inclusion in USF Accountability Reports by an authorized administrator of Digital Commons @ University of South Florida. For more information, please contact digitalcommons@usf.edu. 


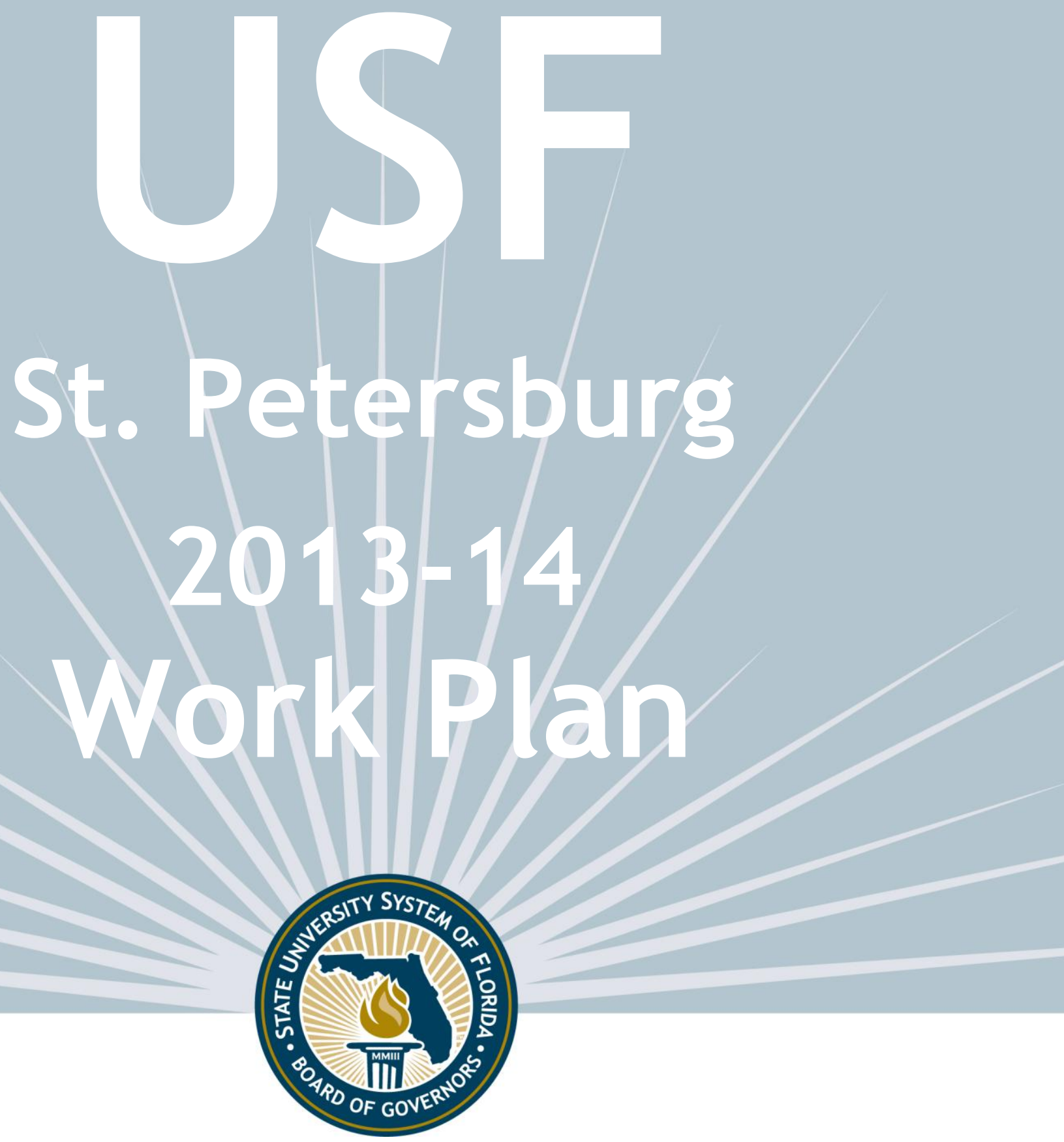

University of South Florida St. Petersburg

Work Plan Presentation for 2013-14 Board of Governors Review

STATE UNIVERSITY SYSTEM of FLORIDA Board of Governors 


\section{INTRODUCTION}

The State University System of Florida has developed three tools that aid in guiding the System's future.

1) The Board of Governors' new Strategic Plan 2012-2025 is driven by goals and associated metrics that stake out where the System is headed;

2) The Board's Annual Accountability Report provides yearly tracking for how the System is progressing toward its goals;

3) Institutional Work Plans connect the two and create an opportunity for greater dialogue relative to how each institution contributes to the System's overall vision.

These three documents assist the Board with strategic planning and with setting short-, mid- and long-term goals. They also enhance the System's commitment to accountability and driving improvements in three primary areas of focus: 1) academic quality, 2) operational efficiency, and 3) return on investment.

The Board will use these documents to help advocate for all System institutions and foster even greater coordination with the institutions and their Boards of Trustees.

Once a Work Plan is approved by each institution's respective Boards of Trustees, the Board of Governors will review and consider the plan for potential acceptance of 2013-14 components. Longer-term components will inform future agendas of the Board's Strategic Planning Committee. The Board's acceptance of a work plan does not constitute approval of any particular component, nor does it supersede any necessary approval processes that may be required for each component. 


\section{TABLE OF CONTENTS}

\section{STRATEGY}
a. Mission Statement
b. Vision Statement
c. Statement of Strategy
d. Strengths and Opportunities
e. Key Initiatives \& Investments

\section{KEY PERFORMANCE INDICATORS}
a. Goals Common to All Universities
b. Goals Specific to Research Universities
c. Institution Specific Goals

\section{OPERATIONS}
a. Fiscal Information (includes Tuition Differential Fee Request)
b. Enrollment Planning
c. Academic Program Coordination

\section{DEFINITIONS}




\section{MISSION STATEMENT (What is your purpose?)}

The University of South Florida St. Petersburg offers distinctive graduate and undergraduate programs in the arts and sciences, business, and education within a close-knit, student-centered learning community that welcomes individuals from the region, state, nation and world. We conduct wideranging, collaborative research to meet society's needs and engage in service projects and partnerships to enhance the university and community's social, economic and intellectual life. As an integral and complementary part of a multi-institutional system, USF St. Petersburg retains a separate identity and mission while contributing to and benefiting from the associations, cooperation, and shared resources of a premier national research university.

\section{VISION STATEMENT (What do you aspire to?)}

The University of South Florida St. Petersburg will be a premier masters degree level urban university recognized for its vibrant community of scholars who engage and improve its community and the world.

\section{STATEMENT OF STRATEGY (How will you get there?)}

Given your mission, vision, strengths and available resources, provide a brief description of your market and your strategy for addressing and leading it.

USFSP's market is driven by its goal to be the masters comprehensive university of choice in the Tampa Bay region and beyond. Recognized by the Carnegie Foundation for the Advancement of Teaching as a community-engaged university, USFSP will continue its strategies of developing and delivering distinctive academic programs for both undergraduate and graduate students that reflect community and regional needs, of nurturing vibrant student-faculty interaction, and of providing student-centered support for curricular and co-curricular activities. It will pursue these strategies through careful financial and environmental stewardship and will utilize appropriate pedagogies, including traditional, mixed delivery and online. It will measure its success through a combination of internal and external measures, including student measures of academic performance, increased student degree completion, and measures of civic engagement. 


\section{STRENGTHS AND OPPORTUNITIES (within 3 years)}

\section{What are your core capabilities, opportunities and challenges for improvement?}

USFSP's core capabilities include excellence in teaching using all forms of delivery, high levels of faculty-student interaction in research, student success, faculty achievement, entrepreneurial spirit, strong and collaborative community engagement, key partnerships, and high accountability for results. USFSP provides students with an intimate intellectual environment to facilitate their growth as active learners and instill life-long habits of the mind. USFSP has high potential for growth in enrollment, even as it retains its institutional character of close faculty-student interactions in the classroom, laboratory, and studio. Careful financial stewardship in a challenging fiscal environment has enabled strategic investments targeted at student success. Academic facilities are a key unmet need as well as financial aid for a student population that is increasingly needy.

\section{KEY INITIATIVES \& INVESTMENTS (within 3 years) \\ Describe your top three key initiatives for the next three years that will drive improvement in Academic Quality, Operational Efficiency, and Return on Investment.}

1. Increase the percentage of residential students as a percent of the total student body.

- Currently USFSP houses about $13 \%$ of its undergraduate student body in university housing.

- National research shows that increased residential living promotes higher retention, greater student participation in co-curricular activities; and higher graduation rates

To reach this goal, USFSP opened 200 additional residential spaces in 2012 increasing the overall residential student numbers by 57\%. In 2013-14 USFSP will increase its focus on the residential experience as a co-curricular activity and will continue to assess potential for increased residential living.

2. Enhance the number and quality of the faculty ranks at USFSP. In order to set the stage for a long future of high quality academic programs, particularly at the graduate level, as well as scholarly productivity and national recognition, USFSP will recruit additional full-time faculty in key disciplines. This will facilitate the continued enhancement of the student experience through increased opportunities for faculty mentorship of student research, including graduate theses; increased engagement of faculty with the community; and increased student retention and degree completion.

3. Refine the strategic enrollment plan developed in 2012-13 and develop and implement a focused initiative for greater student retention and graduation. This will be a coordinated effort involving numerous constituencies and organizational units, including academic advising, tutoring services, wellness and counseling, admissions, residential life and education, student life and engagement, institutional effectiveness, and all academic units. 


\section{KEY PERFORMANCE INDICATORS}

The Board of Governors has selected the following Key Performance Indicators from its 2012-2025 System Strategic Plan and from accountability metrics identified by the Florida Legislature. The Key Performance Indicators emphasize three primary areas of focus: Academic Quality, Operational Efficiency, and Return on Investment. The indicators address common goals across all universities while also providing flexibility to address institution-specific goals from a list of metrics in the 2012-2025 System Strategic Plan.

The Goals Specific to Research Universities apply only to those universities classified by the Carnegie Foundation for the Advancement of Teaching as being a 'Research University' 1 , which includes Florida A\&M University (by university request), Florida Atlantic University, Florida International University, Florida State University, University of Central Florida, University of Florida, and the University of South Florida.

1 The Carnegie Foundation for the Advancement of Teaching has developed a well-respected system of categorizing postsecondary institutions that includes consideration of each doctorate-granting university's research activities - for more information see link. 


\section{KEY PERFORMANCE INDICATORS}

\section{Goals Common to All Universities}

\begin{tabular}{lccccc} 
& 5 YEAR TREND & & & & 3 YEAR \\
& $(2006-07$ to & $2011-12$ & $2012-13$ & $2013-14$ & GOALS \\
Academic Quality & $2011-12)$ & ACTUAL & ESTIMATES & GOALS & $(2015-16)$ \\
\hline
\end{tabular}

\section{National Ranking for University and Programs}

USFSP continues to be ranked highly among regional public universities in the south by US News and World Reports. COB's new global business professor is ranked $10^{\text {th }}$ most prolific scholar; and USFSP continues to seek membership in national honor societies and both the disciplinary and institutional levels.

Avg. SAT Score (for 3 subtests)

Avg. High School GPA

Professional/Licensure Exam

First-time Pass Rates ${ }^{2}$

Exams Above National/State Benchmark

Exams Below National/State Benchmark

Percent of Undergraduate Seniors

Participating in a Research Course

\begin{tabular}{c|cccc}
$.4 \% \Delta^{1}$ & 1602 & 1605 & 1610 & 1620 \\
\hline $0 \% \Delta$ & 3.5 & 3.5 & 3.58 & 3.65 \\
& & & & \\
n/a & n/a & n/a & n/a & n/a \\
n/a & n/a & n/a & n/a & n/a
\end{tabular}

n/a

A system-wide definition will be determined during the Summer of 2013.

\begin{tabular}{|c|c|c|c|c|c|}
\hline SUBTOTAL OF IMPROVING METRICS & $1 / 2$ & & $1 / 2$ & $2 / 2$ & $2 / 2$ \\
\hline \multicolumn{6}{|l|}{ Operational Efficiency } \\
\hline Freshman Retention Rate & $5 \% \Delta$ & $72 \%$ & $73 \%$ & $74 \%$ & $79 \%$ \\
\hline $\begin{array}{l}\text { FTIC Graduation Rates } \\
\text { In } 4 \text { years (or less) } \\
\text { In } 6 \text { years (or less) }\end{array}$ & $\begin{array}{c}6 \% \Delta \\
-.03 \% \Delta\end{array}$ & $\begin{array}{l}27 \% \\
30 \%\end{array}$ & $\begin{array}{l}32 \% \\
32 \%\end{array}$ & $\begin{array}{l}36 \% \\
33 \%\end{array}$ & $\begin{array}{l}45 \% \\
35 \%\end{array}$ \\
\hline $\begin{array}{l}\text { AA Transfer Graduation Rates } \\
\text { In } 2 \text { years (or less) } \\
\text { In } 4 \text { years (or less) }\end{array}$ & $\begin{array}{l}-4 \% \Delta \\
7 \% \Delta\end{array}$ & $\begin{array}{l}27 \% \\
59 \%\end{array}$ & $\begin{array}{l}32 \% \\
60 \%\end{array}$ & $\begin{array}{l}36 \% \\
61 \%\end{array}$ & $\begin{array}{l}44 \% \\
63 \%\end{array}$ \\
\hline $\begin{array}{l}\text { Percent of Bachelor's Degrees } \\
\text { Without Excess Hours }\end{array}$ & N/A & $55 \%$ & $57 \%$ & $60 \%$ & $63 \%$ \\
\hline Average Time to Degree (for FTIC) & $-1 \% \Delta$ & $4.4 \mathrm{yrs}$ & $4.0 \mathrm{yrs}$ & $4.0 \mathrm{yrs}$ & $4.0 \mathrm{yrs}$ \\
\hline SUBTOTAL OF IMPROVING METRICS & $3 / 6$ & & $7 / 7$ & $6 / 7$ & $6 / 7$ \\
\hline \multicolumn{6}{|l|}{ Return on Investment } \\
\hline Bachelor's Degrees Awarded & $.12 \% \Delta$ & 730 & 750 & 760 & 780 \\
\hline Percent of Bachelor's Degrees in STEM & $0 \% \Delta$ & $7 \%$ & $10 \%$ & $12.5 \%$ & $20 \%$ \\
\hline Graduate Degrees Awarded & $0 \% \Delta$ & 144 & 144 & 148 & 168 \\
\hline Percent of Graduate Degrees in STEM & $100 \% \Delta$ & $7 \%$ & $9 \%$ & $10 \%$ & $15 \%$ \\
\hline $\begin{array}{l}\text { Percent of Baccalaureate Graduates } \\
\text { Employed in Florida }\end{array}$ & $-3 \% \Delta^{3}$ & $73 \%^{3}$ & $73 \%$ & $73 \%$ & $73 \%$ \\
\hline $\begin{array}{l}\text { Percent of Baccalaureate Graduates } \\
\text { Continuing their Education (in FL) }\end{array}$ & $-2 \% \Delta^{3}$ & $16 \%{ }^{3}$ & $16 \%$ & $16 \%$ & $16 \%$ \\
\hline Annual Gifts Received $(\$ M)^{*}$ & $\mathrm{n} / \mathrm{a}$ & \multicolumn{4}{|c|}{ Data reported in the USF Work Plan } \\
\hline Endowment $(\$ M)^{*}$ & $\mathrm{n} / \mathrm{a}$ & \multicolumn{4}{|c|}{ Data reported in the USF Work Plan } \\
\hline SUBTOTAL OF IMPROVING METRICS & $2 / 6$ & & $3 / 6$ & $4 / 6$ & $4 / 6$ \\
\hline TOTAL OF IMPROVING METRICS & $6 / 14$ & & $11 / 15$ & $12 / 15$ & $12 / 15$ \\
\hline
\end{tabular}

Notes: (1) SAT trends are based on 4 years, (2) Professional licensure pass rates are based on the 2011-12 Annual Accountability Report with data that spans multiple time periods, (3) Percent of graduates employed and continuing their education is based on 2010-11 data from FETPIP. 


\section{KEY PERFORMANCE INDICATORS}

Goals Specific to Research Universities

\begin{tabular}{|c|c|c|c|c|c|}
\hline & $\begin{array}{l}5 \text { YEAR } \\
\text { TREND } \\
\text { (2005-06 to } \\
2010-11) \\
\end{array}$ & $\begin{array}{c}2010-11 \\
\text { ACTUAL1 }\end{array}$ & $\begin{array}{c}2012-13 \\
\text { ESTIMATES }\end{array}$ & $\begin{array}{l}2013-14 \\
\text { GOALS }\end{array}$ & $\begin{array}{c}3 \text { YEAR } \\
\text { GOALS } \\
(2015-16)\end{array}$ \\
\hline \multicolumn{6}{|l|}{ Academic Quality } \\
\hline Faculty Awards & $\% \Delta$ & $x$ & $x$ & $X$ & $x$ \\
\hline National Academy Members & $\% \Delta$ & $x$ & $x$ & $x$ & $x$ \\
\hline Number of Post-Doctoral Appointees & $\% \Delta$ & $x x^{2}$ & $x x$ & $X x$ & $x x$ \\
\hline $\begin{array}{l}\text { Number of Science \& Engineering } \\
\text { Disciplines Nationally Ranked in Top } 100 \\
\text { for Research Expenditures (based on } 8 \text { broad } \\
\text { discipline areas, and includes private universities) }\end{array}$ & $\mathrm{n} / \mathrm{a}$ & $\begin{array}{c}x \\
\text { of } 8\end{array}$ & $\begin{array}{c}x \\
\text { of } 8\end{array}$ & $\begin{array}{c}x \\
\text { of } 8\end{array}$ & $\begin{array}{c}x \\
\text { of } 8\end{array}$ \\
\hline SUBTOTAL OF IMPROVING METRICS & $\mathbf{x}$ & & $\mathbf{x}$ & $\mathrm{x}$ & $\mathbf{x}$ \\
\hline
\end{tabular}

To Be Determined

\section{Return on Investment}

\section{Total Research Expenditures (\$M)}

(includes non-Science \& Engineering disciplines)

\section{Science \& Engineering Research}

Expenditures (\$M)

Science \& Engineering R\&D Expenditures in Non-Medical/Health Sciences (\$M)

Percent of Research Expenditures funded from External Sources

\section{Patents Issued}

\section{Licenses/Options Executed}

Licensing Income Received (\$M)

\section{Number of Start-up Companies}

National Rank is Higher than Predicted by the Financial Resources Ranking (based on U.S. News \& World Report)

\section{Research Doctoral Degrees Awarded}

Professional Doctoral Degrees Awarded

$$
\text { TOTAL OF IMPROVING METRICS }
$$

The Board of Governors will work with Universities to develop metrics associated with Operational Efficiencies.

\begin{tabular}{cccccc}
\hline SUBTOTAL OF IMPROVING METRICS & $\mathbf{x}$ & $\mathbf{x}$ & $\mathbf{X}$ & $\mathbf{x}$ \\
\hline TOTAL OF IMPROVING METRICS & $\mathbf{x}$ & $\mathbf{x}$ & $\mathbf{X}$ & $\mathbf{x}$
\end{tabular}

Notes: (1) 2011-12 data is not yet available for most of these metrics, so data is based on the 2010-11 year unless indicated otherwise; (2) the most recent Post-Doctoral Appointee data is Fall 2009; (3) indicates 2011-12 data. 


\section{KEY PERFORMANCE INDICATORS}

\section{Institution Specific Goals}

Each university will select three metric goals from the following list of metrics included in the 2012-2025 System Strategic Plan:

\begin{tabular}{|c|c|}
\hline Freshman in Top $10 \%$ of Graduating High School Class & Bachelor's Degrees in Areas of Strategic Emphasis \\
\hline Percentage of Eligible Programs with Specialized Accreditation & Graduate Degrees in Areas of Strategic Emphasis \\
\hline Bachelor's Degrees Awarded to Minorities & Number of Faculty Designated a Highly Cited Scholar \\
\hline Number of Adult (age 25+) Undergraduates Enrolled & $\begin{array}{l}\text { Seek and/or Maintain Carnegie's Community } \\
\text { Engagement Classification (narrative goal) }\end{array}$ \\
\hline \multirow[t]{2}{*}{$\begin{array}{l}\text { Percent of Course Sections Offered via Distance and Blended } \\
\text { Learning }\end{array}$} & $\begin{array}{l}\text { Percentage of Students Participating in Identified } \\
\text { Community and Business Engagement Activities }\end{array}$ \\
\hline & $\begin{array}{l}\text { Enrollment in Professional Training and Continuing } \\
\text { Education Courses }\end{array}$ \\
\hline
\end{tabular}

\begin{tabular}{lccccc} 
& $\begin{array}{c}\text { 5 YEAR } \\
\text { TREND } \\
\text { (2006-07 to } \\
\text { 2011-12) }\end{array}$ & $\begin{array}{c}\text { 2011-12 } \\
\text { ACTUAL }\end{array}$ & $\begin{array}{c}\text { 2012-13 } \\
\text { ESTIMATES }\end{array}$ & $\begin{array}{c}\text { 2013-14 } \\
\text { GOALS }\end{array}$ & $\begin{array}{c}\text { 3 YEAR GOALS } \\
\text { (2015-16) }\end{array}$ \\
\hline $\begin{array}{l}\text { Bachelor's Degrees in Areas of Strategic Emphasis } \\
65 \% \Delta\end{array}$ & 178 & 200 & 200 & 225 \\
\hline $\begin{array}{l}\text { Percent of Course Sections Offered via Distance } \\
\text { and Blended Learning }\end{array}$ & Not avail. & $16 \%$ & $19 \%$ & $22 \%$ & $25 \%$ \\
\hline $\begin{array}{l}\text { Maintain Carnegie Community Engagement } \\
\text { Classification }\end{array}$ & $100 \% *$ & & & & \\
\hline
\end{tabular}

To further distinguish the university's distinctive mission, the university may choose to provide two additional narrative and metric goals that are based on the university's own strategic plan.

Goal 1. Improve baccalaureate retention and graduation (USF System Goal 1); USFSP will focus on improving student outcomes in key mathematics courses through continued implementation of its Quality Enhancement Plan; focus on improving access to academic support (i.e., tutoring); continued emphasis on strengthening academic advising.

Metric: Increase 6-year FTIC baccalaureate graduation rate

\begin{tabular}{|c|c|c|c|}
\hline $0 \% \Delta$ & $30 \%$ & $32 \%$ & $33 \%$ \\
\hline
\end{tabular}

*USFSP earned this designation in 2011-12 and will retain this designation through 2015, the next application cycle. 


\section{OPERATIONS}




\section{FISCAL INFORMATION}

University Revenues (in Millions of Dollars)

\begin{tabular}{|c|c|c|c|c|c|c|}
\hline & $\begin{array}{c}2008-09 \\
\text { Actual }\end{array}$ & $\begin{array}{c}2009-10 \\
\text { Actual }\end{array}$ & $\begin{array}{c}2010-11 \\
\text { Actual }\end{array}$ & $\begin{array}{c}2011-12 \\
\text { Actual }\end{array}$ & $\begin{array}{c}2012-13 \\
\text { Actual }\end{array}$ & $\begin{array}{c}\text { 2013-14 } \\
\text { Appropriations }\end{array}$ \\
\hline \multicolumn{7}{|c|}{ Education \& General - Main Operations } \\
\hline State Funds & $\$ 26.1$ & $\$ 24.6$ & $\$ 24.4$ & $\$ 21.0$ & $\$ 15.9$ & $\mathrm{n} / \mathrm{a}$ \\
\hline Tuition & $\$ 10.7$ & $\$ 12.9$ & \$14.7 & $\$ 17.8$ & $\$ 21.2$ & $\mathrm{n} / \mathrm{a}$ \\
\hline TOTAL MAIN OPERATIONS & $\$ 36.7$ & $\$ 37.5$ & $\$ 39.1$ & $\$ 38.8$ & $\$ 37.1$ & n/a \\
\hline \multicolumn{7}{|c|}{ Education \& General - Health-Science Center / Medical Schools } \\
\hline State Funds & $\mathrm{n} / \mathrm{a}$ & $\mathrm{n} / \mathrm{a}$ & $\mathrm{n} / \mathrm{a}$ & $\mathrm{n} / \mathrm{a}$ & $\mathrm{n} / \mathrm{a}$ & $\mathrm{n} / \mathrm{a}$ \\
\hline Tuition & $\mathrm{n} / \mathrm{a}$ & n/a & $\mathrm{n} / \mathrm{a}$ & $\mathrm{n} / \mathrm{a}$ & $\mathrm{n} / \mathrm{a}$ & $\mathrm{n} / \mathrm{a}$ \\
\hline TOTAL HSC & $\mathrm{n} / \mathrm{a}$ & $\mathrm{n} / \mathrm{a}$ & $\mathrm{n} / \mathrm{a}$ & $\mathrm{n} / \mathrm{a}$ & $\mathrm{n} / \mathrm{a}$ & $\mathrm{n} / \mathrm{a}$ \\
\hline \multicolumn{7}{|c|}{ Education \& General - Institute of Food \& Agricultural Sciences (IFAS) } \\
\hline State Funds & n/a & n/a & $\mathrm{n} / \mathrm{a}$ & $\mathrm{n} / \mathrm{a}$ & $\mathrm{n} / \mathrm{a}$ & $\mathrm{n} / \mathrm{a}$ \\
\hline Tuition & $\mathrm{n} / \mathrm{a}$ & n/a & $\mathrm{n} / \mathrm{a}$ & $\mathrm{n} / \mathrm{a}$ & $\mathrm{n} / \mathrm{a}$ & $\mathrm{n} / \mathrm{a}$ \\
\hline TOTAL IFAS & $\mathrm{n} / \mathrm{a}$ & $\mathrm{n} / \mathrm{a}$ & $\mathrm{n} / \mathrm{a}$ & $\mathrm{n} / \mathrm{a}$ & $\mathrm{n} / \mathrm{a}$ & $\mathrm{n} / \mathrm{a}$ \\
\hline $\begin{array}{l}\text { EDUCATION \& GENERAL } \\
\text { TOTAL REVENUES }\end{array}$ & $\$ 36.7$ & $\$ 37.5$ & $\$ 39.1$ & $\$ 38.8$ & $\$ 37.1$ & $\mathrm{n} / \mathrm{a}$ \\
\hline
\end{tabular}

Note: State funds include General Revenue funds, Lottery funds, Federal Stimulus funds, and Phosphate Research funds (for Polytechnic) appropriated by the Florida Legislature (as reported in the Annual Accountability Report). Actual tuition includes base tuition and tuition differential fee revenues for resident and non-resident undergraduate and graduate students net of waivers (as reported in the Annual Accountability Report). Actual tuition revenues are not yet available for the 2013-14 year.

\section{Auxiliary Enterprises}

Resources associated with auxiliary units that are self supporting through fees, payments and charges. Examples include housing, food services, bookstores, parking services, health centers.

$\begin{array}{lcccc}\text { Revenues } & \begin{array}{c}\text { USF System } \\ \text { Level }\end{array} & \$ 8,207,956 & \$ 13,154,977 & \text { n/a }\end{array}$

\section{Contracts \& Grants}

Resources received from federal, state or private sources for the purposes of conducting research and public service activities.

\begin{tabular}{ccccc}
\hline Revenues & $\begin{array}{c}\text { USF System } \\
\text { Level }\end{array}$ & $\$ 3,228,779$ & $\$ 3,750,000$ & n/a \\
\hline
\end{tabular}

\section{Local Funds}

Resources associated with student activity (supported by the student activity fee), student financial aid, concessions, intercollegiate athletics, technology fee, green fee, and student life \& services fee.

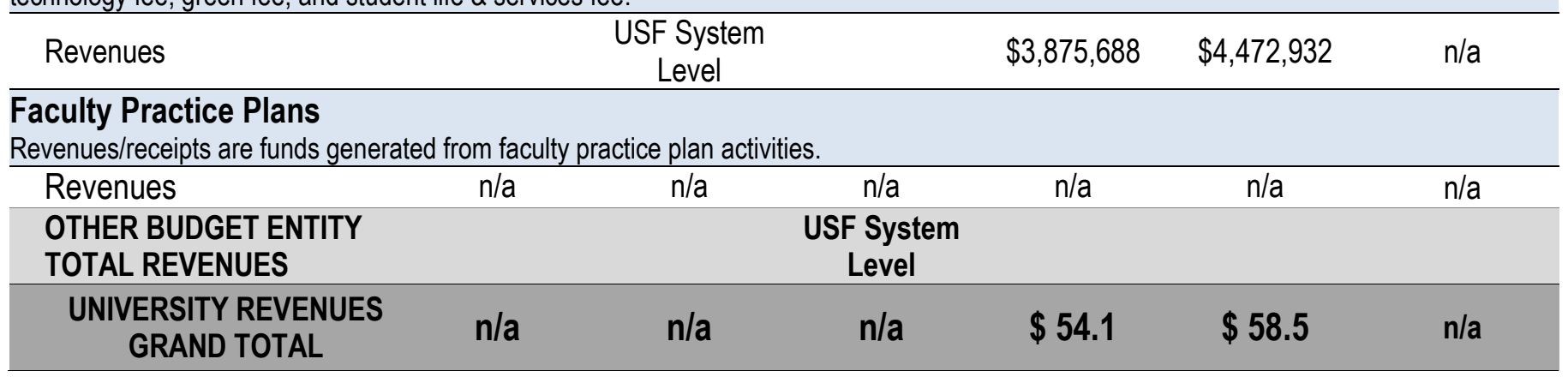




\section{FISCAL INFORMATION (continued)}

Undergraduate Resident Tuition Summary (for 30 credit hours)

\begin{tabular}{lccccc} 
& $\begin{array}{c}\text { FY 2011-12 } \\
\text { ACTUAL }\end{array}$ & $\begin{array}{c}\text { FY 2012-13 } \\
\text { ACTUAL }\end{array}$ & $\begin{array}{c}\text { FY 2013-14 } \\
\text { REQUEST }\end{array}$ & $\begin{array}{c}\text { FY 2014-15 } \\
\text { PLANNED }\end{array}$ & $\begin{array}{c}\text { FY 2015-16 } \\
\text { PLANNED }\end{array}$ \\
\hline Base Tuition & $\$ 3,100$ & $\$ 3,100$ & $\$ 3,152$ & $\$ 3,152$ & $\$ 3,152$ \\
\hline Tuition Differential Fee & $\$ 643$ & $\$ 1,054$ & $\$ 1,054$ & $\$ 1,054$ & $\$ 1,054$ \\
\hline Percent Increase & $15 \%$ & $11 \%$ & $1.3 \%$ & $0 \%$ & $0 \%$ \\
\hline Required Fees & $\$, 1457$ & $\$ 1,562$ & $\$ 1,615$ & $\$ 1,615$ & $\$ 1,615$ \\
\hline TOTAL TUITION AND FEES & $\$ 5,199$ & $\$ 5,716$ & $\$ 5,821$ & $\$ 5,821$ & $\$ 5,821$
\end{tabular}

Note 1: For more information regarding required fees see list of per credit hour fees and block fees on page 16.

\section{Student Debt Summary}

\begin{tabular}{|c|c|c|c|c|c|c|}
\hline & & $\begin{array}{r}2008-09 \\
\text { ACTUAL } \\
\end{array}$ & $\begin{array}{r}2009-10 \\
\text { ACTUAL }\end{array}$ & $\begin{array}{r}2010-11 \\
\text { ACTUAL } \\
\end{array}$ & $\begin{array}{r}2011-12 \\
\text { ACTUAL } \\
\end{array}$ & $\begin{array}{c}2012-13 \\
\text { ESTIMATE }\end{array}$ \\
\hline \multicolumn{2}{|c|}{ Percent of Bachelor's Recipients with Debt } & $42 \%$ & $40 \%$ & $48 \%$ & $48 \%$ & $48 \%$ \\
\hline \multicolumn{2}{|c|}{$\begin{array}{l}\text { Average Amount of Debt } \\
\text { for Bachelor's who have graduated with debt }\end{array}$} & $\$ 20,181$ & $\$ 20,827$ & $\$ 22,836$ & $\$ 24,096$ & $\$ 24,000$ \\
\hline \multicolumn{2}{|c|}{ Student Loan Cohort Default Rate (2nd Year) ${ }^{*}$} & $7.0 \%$ & $6.8 \%$ & $5.5 \%$ draft & $\mathrm{n} / \mathrm{a}$ & $\mathrm{n} / \mathrm{a}$ \\
\hline \multicolumn{4}{|c|}{$\begin{array}{l}\text { Student Loan Cohort Default Rate }(3 r d \text { Year)* } \\
\text { Note: Student Loan cohort default data includes undergraduate and graduate students. } \\
\text { *USF System data }\end{array}$} & $\mathrm{n} / \mathrm{a}$ & $\mathrm{n} / \mathrm{a}$ & $\mathrm{n} / \mathrm{a}$ \\
\hline \multicolumn{7}{|c|}{ Cost of Attendance (for Full-Time Undergraduate Florida Residents in the Fall and Spring of 2012-13) } \\
\hline & $\begin{array}{ll}\text { TUITION } & \text { BOOKS \& } \\
\& \text { FEES } & \text { SUPPLIES } \\
\end{array}$ & $\begin{array}{l}\text { ROOM } \\
\& \text { BOARD }\end{array}$ & \multicolumn{2}{|c|}{ TRANSPORTATION } & $\begin{array}{l}\text { OTHER } \\
\text { EXPENSES }\end{array}$ & TOTAL \\
\hline ON-CAMPUS & $\$ 1,000$ & $\$ 8,960$ & \multicolumn{2}{|c|}{$\$ 1,600$} & $\$ 2,500$ & $\$ 19,776$ \\
\hline AT HOME & $\$ 5,716$ & $\$ 4,480$ & \multicolumn{2}{|c|}{$\$ 1,600$} & $\$ 2,500$ & $\$ 15,296$ \\
\hline
\end{tabular}

Estimated Net Cost by Family Income (for Full-Time Undergraduate Florida Residents in the Fall and Spring of 2012-13)

\begin{tabular}{|c|c|c|c|c|c|c|}
\hline \multirow{2}{*}{$\begin{array}{l}\text { FAMILY } \\
\text { INCOME } \\
\text { GROUPS }\end{array}$} & \multicolumn{2}{|c|}{$\begin{array}{c}\text { FULL-TIME RESIDENT } \\
\text { UNDERGRADUATES }\end{array}$} & \multirow{2}{*}{$\begin{array}{c}\text { AVG. NET } \\
\text { COST OF } \\
\text { ATTENDANCE }\end{array}$} & \multirow{2}{*}{$\begin{array}{c}\text { AVG. NET } \\
\text { TUITION } \\
\text { \& FEES }\end{array}$} & \multirow{2}{*}{$\begin{array}{l}\text { AVERAGE } \\
\text { GIFT AID } \\
\text { AMOUNT }\end{array}$} & \multirow{2}{*}{$\begin{array}{c}\text { AVERAGE } \\
\text { LOAN } \\
\text { AMOUNT }\end{array}$} \\
\hline & HEADCOUNT & PERCENT & & & & \\
\hline Below $\$ 40,000$ & 757 & $37 \%$ & $\$ 11,450$ & $-\$ 2,227$ & $\$ 7,485$ & $\$ 4,468$ \\
\hline$\$ 40,000-\$ 59,999$ & 262 & $13 \%$ & $\$ 13,576$ & $\$ 291$ & $\$ 4,970$ & $\$ 3,777$ \\
\hline$\$ 60,000-\$ 79,999$ & 208 & $10 \%$ & $\$ 15,010$ & $\$ 2,209$ & $\$ 3,141$ & $\$ 4,155$ \\
\hline$\$ 80,000-\$ 99,999$ & 190 & $9 \%$ & $\$ 15,452$ & $\$ 2,869$ & $\$ 2,612$ & $\$ 4,477$ \\
\hline$\$ 100,000$ Above & 457 & $23 \%$ & $\$ 16,463$ & $\$ 3,448$ & $\$ 1,860$ & $\$ 3,057$ \\
\hline Missing & 163 & $8 \%$ & $\$ 19,464$ & $\$ 5,206$ & $\$ 139$ & $\$ 129$ \\
\hline TOTAL & 2,037 & $100 \%$ & $\$ 14,226$ & $\$ 899$ & $\$ 4,414$ & $\$ 3,684$ \\
\hline
\end{tabular}

Notes: This data only represents Fall and Spring financial aid data and is accurate as of March 31, 2013. Please note that small changes to Spring 2013 awards are possible before the data is finalized. Family Income Groups are based on the Total Family Income (including untaxed income) as reported on student FAFSA records. Full-time Students is a headcount based on at least 24 credit hours during Fall and Spring terms. Average Gift Aid includes all grants and scholarships from Federal, State, University and other private sources administered by the Financial Aid Office. Student waivers are also included in the Gift Aid amount. Gift Aid does not include the parental contribution towards EFC. Net Cost of Attendance is the actual average of the total Costs of Attendance (which will vary by income group due to the diversity of students living on- \& off- campus) minus the average Gift Aid amount. Net Tuition \& Fees is the actual average of the total costs of tuition and fees (which will vary by income group due to the amount of credit hours students are enrolled) minus the average Gift Aid amount (see page 16 for list of fees that are included). Average Loan Amount includes Federal (Perkins, Stafford, Ford Direct, and PLUS loans) and all private loans. The bottom-line Average represents the average of all full-time undergraduate Florida residents. 


\section{FISCAL INFORMATION (continued) \\ TUITION DIFFERENTIAL FEE INCREASE REQUEST FOR FALL 2013}

\section{Effective Date}

University Board of Trustees approval date:

\section{Campus or Center Location}

Campus or center location to which the tuition differential fee increase will apply (If the entire university, indicate as such):

\section{Undergraduate Course(s)}

Course(s). (If the tuition differential fee applies to all university undergraduate courses, indicate as such. If not, provide rationale for the differentiation among courses):

\section{Current and Proposed Increase in the Tuition Differential Fee}

\section{Current Undergraduate Tuition Differential per credit hour:}

Percentage tuition differential fee increase (calculated as a percentage of the sum of base tuition plus tuition differential):

$\$$ Increase in tuition differential per credit hour:

$\$$ Increase in tuition differential for 30 credit hours: $\$ 35.14$

\section{Projected Differential Revenue Generated}

Incremental revenue generated in 2013-14 (projected):

Total differential fee revenue generated in 2013-14 (projected): $\$ 0$

$\$ 3,599,109$

\section{Intended Uses}

Describe how the revenue will be used.

Cost-efficient utilization of instructional technology and innovation, along with investments in faculty and professional staff to enhance timely college completion rates, attainment and career placement through activities such as:

-Need-Based Financial Aid (at 40\%): Expand access for students; and accelerated path to graduation. Provide much needed financial support for talented students with limited income.

-Expanding the High Skilled Workforce and Supporting Job Placement: Expanded degree production in Areas of Strategic Emphasis; Strengthened relationships with business and industry; Increased number of internships; Expanded professional support for job placement through USFSP's Career Center.

- Academic Advising: Enhanced academic advising through technology and additional professional staff; focus on goal setting, time-to-degree, improved graduation rates, reducing excess hours. Improved tracking of students and graduates.

\section{Describe the Impact to the Institution if Tuition Differential is Not Approved}

\section{Request to Modify or Waive Tuition Differential Uses}

(pursuant to Section 1001.706(3)(g) the Board may consider waiving its regulations associated with the $70 \% / 30 \%$ intended uses criteria identified in Regulation 7.001(14). If the university requests a modification; identify the modification, purpose of the modification, and rationale for the modification.) 


\section{FISCAL INFORMATION (continued) TUITION DIFFERENTIAL SUPPLEMENTAL INFORMATION}

Provide the following information for the 2012-13 academic year.

$\begin{gathered}2012-2013-60 \% \text { Initiatives (list the initiatives provided in } \\ \text { the 2012-13 tuition differential request) }\end{gathered}$
Improve graduation rates through QEP implementation

Increase faculty/student research and creative activity

Enhanced undergraduate programs

\section{University Update on Each Initiative}

Two new faculty hired to support QEP; revised implementation plan to enhance student success; enhanced tutoring; increase in FTIC graduation rate

Research funding at all-time high. Increased student presentations, research posters and papers and student research awards. First national student research award. New degree in Biology launched, new faculty in Education, senior faculty in Business

\section{Additional Detail, where applicable:}

Total Number of Faculty Hired or Retained (funded by tuition 26

differential):

Total Number of Advisors Hired or Retained (funded by tuition differential):

Total Number of Course Sections Added or Saved (funded by tuition differential):

\section{2-2013 - 40\% Initiatives (list the initiatives provided in the 2012-13 tuition differential request)}

Expand access for students and accelerated path to graduation

Provide financial support for students with limited income

More students supported with financial aid scholarships and reduced loan indebtedness

\section{Additional Information (estimates as of April 30, 2013):}

Two senior students were incentivized to graduate in four years with a $\$ 2,500$ grant which will repay $\$ 2,500$ in student loans if the student graduated in spring 2013. Awards will be made once degree verification can be confirmed.

Larger USF need based grant awards were made to students based on their academic potential and USF academic record. The number of students receiving a need based grant increased from 509 to 809 , or by $59 \%$.
Unduplicated Count of Students Receiving at least one

Tuition Differential-Funded Award:

\$ Mean (per student receiving an award) of Tuition

Differential-Funded Awards:

\$ Minimum (per student receiving an award) of Tuition

Differential-Funded Awards:

\$ Maximum (per student receiving an award) of Tuition

Differential-Funded Awards:
809

1,308

250

2,500 


\section{FISCAL INFORMATION (continued)}

TUITION DIFFERENTIAL COLLECTIONS, EXPENDITURES, \& AVAILABLE BALANCES - FISCAL YEAR 2012-13 AND 2013-14

\begin{tabular}{|c|c|c|c|c|}
\hline \multicolumn{5}{|c|}{ University Tuition Differential } \\
\hline Budget Entity: 48900100 (Educational \& Genera & & & & \\
\hline & & & \multirow{2}{*}{\multicolumn{2}{|c|}{$\begin{array}{l}\text { Estimated } \\
\text { 2013-14 }\end{array}$}} \\
\hline & \multicolumn{2}{|r|}{$\begin{array}{c}\text { Estimated Actual* } \\
2012-13\end{array}$} & & \\
\hline \multicolumn{5}{|l|}{ FTE Positions: } \\
\hline Faculty & & 25.06 & & 32.0 . \\
\hline Advisors & & 2.00 & & 4.0 \\
\hline Staff & & 8.08 & & 8.0. \\
\hline Total FTE Positions: & & 35.06 & & 44.0 \\
\hline \multicolumn{5}{|l|}{ Balance Forward from Prior Periods } \\
\hline $\begin{array}{l}\text { Balance Forward } \\
\text { Less: Prior-Year Encumbrances }\end{array}$ & $\$$ & $\begin{array}{r}475,306 \\
-\end{array}$ & $\$$ & 513,586 \\
\hline Beginning Balance Available: & $\$$ & 475,306 & $\$$ & 513,586 \\
\hline \multicolumn{5}{|l|}{ Receipts / Revenues } \\
\hline Tuition Differential Collections & $\$$ & $3,472,400$ & & $3,599,109$ \\
\hline Interest Revenue - Current Year & & 2,000 & & 2,070 \\
\hline Interest Revenue - From Carryforward Balance & & 1,000 & & 1,035 \\
\hline Total Receipts / Revenues: & $\$$ & $3,480,400$ & $\$$ & $3,602,214$ \\
\hline \multicolumn{5}{|l|}{ Expenditures } \\
\hline Salaries \& Benefits & $\$$ & $1,775,264$ & $\$$ & $2,379,514$ \\
\hline Other Personal Services & & - & & - \\
\hline Expenses & & 12,000 & & 12,000 \\
\hline Operating Capital Outlay & & - & & - \\
\hline Student Financial Assistance & & $1,179,856$ & & $1,221,150$ \\
\hline Expended From Carryforward Balance & & 475,000 & & 500,000 \\
\hline${ }^{* \star}$ Other Category Expenditures & & - & & - \\
\hline Total Expenditures: & $\$$ & $3,442,120$ & $\$$ & $4,112,664$ \\
\hline Ending Balance Available: & $\$$ & 513,586 & $\$$ & 3,136 \\
\hline
\end{tabular}




\section{FISCAL INFORMATION (continued) UNIVERSITY TUITION, FEES AND HOUSING PROJECTIONS}

\begin{tabular}{|c|c|c|c|c|c|c|c|c|}
\hline \multicolumn{9}{|l|}{ University of South Florida - St. Petersburg } \\
\hline \multirow{2}{*}{ Undergraduate Students } & \multicolumn{3}{|c|}{ Actual-m- } & \multicolumn{5}{|c|}{ 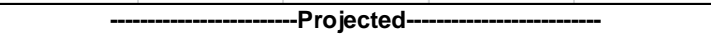 } \\
\hline & 2010-11 & 2011-12 & 2012-13 & 2013-14 & 2014-15 & 2015-16 & 2016-17 & 2017-18 \\
\hline \multicolumn{9}{|l|}{ Tuition: } \\
\hline Base Tuition - & $\$ 95.67$ & $\$ 103.32$ & $\$ 103.32$ & $\$ 105.07$ & $\$ 105.07$ & $\$ 105.07$ & $\$ 105.07$ & $\$ 105.07$ \\
\hline Tuition Differential (no more than 15\%) & $\$ 12.80$ & $\$ 21.42$ & $\$ 35.14$ & $\$ 35.14$ & $\$ 35.14$ & $\$ 35.14$ & $\$ 35.14$ & $\$ 35.14$ \\
\hline Total Base Tuition and Differential & $\$ 108.47$ & $\$ 124.74$ & $\$ 138.46$ & $\$ 140.21$ & $\$ 140.21$ & $\$ 140.21$ & $\$ 140.21$ & $\$ 140.21$ \\
\hline $\begin{array}{c}\text { Change } \\
\end{array}$ & $15.0 \%$ & $15.0 \%$ & $11.0 \%$ & $1.3 \%$ & $0.0 \%$ & $0.0 \%$ & $0.0 \%$ & $0.0 \%$ \\
\hline \multicolumn{9}{|l|}{ Fees (per credit hour): } \\
\hline$\overline{\text { Student Financial Aid' }}$ & $\$ 4.78$ & $\$ 5.16$ & $\$ 5.16$ & $\$ 5.25$ & $\$ 5.25$ & $\$ 5.25$ & $\$ 5.25$ & $\$ 5.25$ \\
\hline Building/Capital Improvement ${ }^{2}$ & $\$ 4.76$ & $\$ 4.76$ & $\$ 6.76$ & $\$ 6.76$ & $\$ 6.76$ & $\$ 6.76$ & $\$ 6.76$ & $\$ 6.76$ \\
\hline Activity \& Service & $\$ 24.80$ & $\$ 24.80$ & $\$ 25.05$ & $\$ 25.63$ & $\$ 25.63$ & $\$ 25.63$ & $\$ 25.63$ & $\$ 25.63$ \\
\hline Health & $\$ 1.20$ & $\$ 2.64$ & $\$ 3.90$ & $\$ 4.90$ & $\$ 4.90$ & $\$ 4.90$ & $\$ 4.90$ & $\$ 4.90$ \\
\hline Athletic & $\$ 2.45$ & $\$ 2.45$ & $\$ 2.45$ & $\$ 2.45$ & $\$ 2.45$ & $\$ 2.45$ & $\$ 2.45$ & $\$ 2.45$ \\
\hline Transportation Access & $\$ 2.25$ & $\$ 2.25$ & $\$ 2.25$ & $\$ 2.25$ & $\$ 2.25$ & $\$ 2.25$ & $\$ 2.25$ & $\$ 2.25$ \\
\hline Technology ${ }^{1}$ & $\$ 4.78$ & $\$ 5.16$ & $\$ 5.16$ & $\$ 5.25^{\prime \prime}$ & $\$ 5.25 "$ & $\$ 5.25^{\prime}$ & $\$ 5.25^{\prime}$ & $\$ 5.25$ \\
\hline Student Green Energy & & $\$ 1.00$ & $\$ 1.00$ & $\$ 1.00$ & $\$ 1.00$ & $\$ 1.00$ & $\$ 1.00$ & $\$ 1.00$ \\
\hline Sub total (credit hour fees) & $\$ 45.02$ & $\$ 48.22$ & $\$ 51.73$ & $\$ 53.49$ & $\$ 53.49$ & $\$ 53.49$ & $\$ 53.49$ & $\$ 53.49$ \\
\hline Total Tuition and Fees per credit hour & $\$ 153.49$ & $\$ 172.96$ & $\$ 190.19$ & $\$ 193.70$ & $\$ 193.70$ & $\$ 193.70$ & $\$ 193.70$ & $\$ 193.70$ \\
\hline \% Change & $24.4 \%$ & $12.7 \%$ & $10.0 \%$ & $1.8 \%$ & $0.0 \%$ & $0.0 \%$ & $0.0 \%$ & $0.0 \%$ \\
\hline \multicolumn{9}{|l|}{ Fees (block per term): } \\
\hline \multicolumn{9}{|l|}{ Activity \& Service } \\
\hline \multicolumn{9}{|l|}{ Health } \\
\hline Athletic & $\$ 5.00$ & $\$ 5.00$ & $\$ 5.00$ & $\$ 5.00$ & $\$ 5.00$ & $\$ 5.00$ & $\$ 5.00$ & $\$ 5.00$ \\
\hline \multicolumn{9}{|l|}{ Transportation Access } \\
\hline Total Block Fees per term & $\$ 5.00$ & $\$ 5.00$ & $\$ 5.00$ & $\$ 5.00$ & $\$ 5.00$ & $\$ 5.00$ & $\$ 5.00$ & $\$ 5.00$ \\
\hline$\%$ Change & $0.0 \%$ & $0.0 \%$ & $0.0 \%$ & $0.0 \%$ & $0.0 \%$ & $0.0 \%$ & $0.0 \%$ & $0.0 \%$ \\
\hline Total Tuition for 30 Credit Hours & $\$ 3,254.10$ & $\$ 3,742.20$ & $\$ 4,153.80$ & $\$ 4,206.30$ & $\$ 4,206.30$ & $\$ 4,206.30$ & $\$ 4,206.30$ & $\$ 4,206.30$ \\
\hline Total Fees for 30 Credit Hours & $\$ 1,360.60$ & $\$ 1,456.60$ & $\$ 1,561.90$ & $\$ 1,614.70$ & $\$ 1,614.70$ & $\$ 1,614.70$ & $\$ 1,614.70$ & $\$ 1,614.70$ \\
\hline Total Tuition and Fees for 30 Credit Hours & $\$ 4,614.70$ & $\$ 5,198.80$ & $\$ 5,715.70$ & $\$ 5,821.00$ & $\$ 5,821.00$ & $\$ 5,821.00$ & $\$ 5,821.00$ & $\$ 5,821.00$ \\
\hline \$Change & $\$ 901.80$ & $\$ 584.10$ & $\$ 516.90$ & $\$ 105.30$ & $\$ 0.00$ & $\$ 0.00$ & $\$ 0.00$ & $\$ 0.00$ \\
\hline$\%$ Change & $24.3 \%$ & $12.7 \%$ & $9.9 \%$ & $1.8 \%$ & $0.0 \%$ & $0.0 \%$ & $0.0 \%$ & $0.0 \%$ \\
\hline \multicolumn{9}{|l|}{ Out-of-State Fees } \\
\hline$\overline{\text { Out-of-State Undergraduate Fee }}$ & $\$ 343.16$ & $\$ 291.68$ & $\$ 315.00$ & $\$ 346.50$ & $\$ 346.50$ & $\$ 346.50$ & $\$ 346.50$ & $\$ 346.50$ \\
\hline Out-of-State Undergraduate Student Financial Aid ${ }^{3}$ & $\$ 17.15$ & $\$ 14.58$ & $\$ 15.75$ & $\$ 17.32$ & $\$ 17.32$ & $\$ 17.32$ & $\$ 17.32$ & $\$ 17.32$ \\
\hline Total per credit hour & $\$ 360.31$ & $\$ 306.26$ & $\$ 330.75$ & $\$ 363.82$ & $\$ 363.82$ & $\$ 363.82$ & $\$ 363.82$ & $\$ 363.82$ \\
\hline $\begin{array}{c}\text { Change } \\
\end{array}$ & $0 \%$ & $-15 \%$ & $8 \%$ & $10 \%$ & $0 \%$ & $0 \%$ & $0 \%$ & $0 \%$ \\
\hline Total Tuition for 30 Credit Hours & $\$ 3,254.10$ & $\$ 3,742.20$ & $\$ 4,153.80$ & $\$ 4,206.30$ & $\$ 4,206.30$ & $\$ 4,206.30$ & $\$ 4,206.30$ & $\$ 4,206.30$ \\
\hline Total Fees for 30 Credit Hours & $\$ 12,169.90$ & $\$ 10,644.40$ & $\$ 11,484.40$ & $\$ 12,529.30$ & $\$ 12,529.30$ & $\$ 12,529.30$ & $\$ 12,529.30$ & $\$ 12,529.30$ \\
\hline Total Tuition and Fees for 30 Credit Hours & $\$ 15,424.00$ & $\$ 14,386.60$ & $\$ 15,638.20$ & $\$ 16,735.60$ & $\$ 16,735.60$ & $\$ 16,735.60$ & $\$ 16,735.60$ & $\$ 16,735.60$ \\
\hline \$Change & $\$ 901.80$ & $-\$ 1,037.40$ & $\$ 1,251.60$ & $\$ 1,097.40$ & $\$ 0.00$ & $\$ 0.00$ & $\$ 0.00$ & $\$ 0.00$ \\
\hline$\%$ Change & $6.2 \%$ & $-6.7 \%$ & $8.7 \%$ & $7.0 \%$ & $0.0 \%$ & $0.0 \%$ & $0.0 \%$ & $0.0 \%$ \\
\hline \multicolumn{9}{|l|}{ Housing/Dining } \\
\hline$\%$ Change & & \#DIV/O! & \#REF! & \#DIV/0! & \#DIV/O! & \#DIV/O! & \#DIV/O! & \#DIV/0! \\
\hline
\end{tabular}




\section{ENROLLMENT PLANNING}

Planned Growth by Student Type (for all E\&G students at all campuses)

\begin{tabular}{|c|c|c|c|c|c|c|c|c|c|}
\hline \multirow{2}{*}{ UNDERGRADUATE } & \multirow[t]{2}{*}{$\begin{array}{c}5 \text { YEAR } \\
\text { TREND } \\
\text { (2006-07 to } \\
2011-12) \\
\end{array}$} & \multicolumn{2}{|c|}{$\begin{array}{c}\text { 2011-12 } \\
\text { ACTUAL } \\
\text { HEADCOUNT }\end{array}$} & \multicolumn{2}{|c|}{$\begin{array}{c}\text { 2013-14 } \\
\text { PLANNED } \\
\text { HEADCOUNT }\end{array}$} & \multicolumn{2}{|c|}{$\begin{array}{c}2014-15 \\
\text { PLANNED } \\
\text { HEADCOUNT }\end{array}$} & \multicolumn{2}{|c|}{$\begin{array}{c}2015-16 \\
\text { PLANNED } \\
\text { HEADCOUNT }\end{array}$} \\
\hline & & & & & & & & & \\
\hline FTIC (Regular Admit) & $69 \% \Delta$ & 606 & $33 \%$ & 758 & $39 \%$ & 785 & $39 \%$ & 812 & $39 \%$ \\
\hline FTIC (Profile Admit) & $88 \% \Delta$ & 9 & $1 \%$ & 15 & $1 \%$ & 16 & $1 \%$ & 16 & $1 \%$ \\
\hline AA Transfers* & $12 \% \Delta$ & 723 & $39 \%$ & 727 & $38 \%$ & 752 & $38 \%$ & 778 & $38 \%$ \\
\hline Other Transfers & $15 \% \Delta$ & 497 & $22 \%$ & 426 & $22 \%$ & 441 & $22 \%$ & 456 & $22 \%$ \\
\hline Subtotal & $30 \% \Delta$ & 1835 & $100 \%$ & 1927 & $100 \%$ & 1994 & $100 \%$ & 2062 & $100 \%$ \\
\hline \multicolumn{10}{|l|}{ GRADUATE STUDENTS } \\
\hline Master's & $16 \% \Delta$ & 214 & $100 \%$ & 293 & $100 \%$ & 303 & $100 \%$ & 314 & $100 \%$ \\
\hline Research Doctoral & $0 \% \Delta$ & $\mathrm{n} / \mathrm{a}$ & $x x \%$ & $\mathrm{n} / \mathrm{a}$ & $x x \%$ & $\mathrm{n} / \mathrm{a}$ & $x x \%$ & $\mathrm{n} / \mathrm{a}$ & $x x \%$ \\
\hline Professional Doctoral & $0 \% \Delta$ & $\mathrm{n} / \mathrm{a}$ & $x x \%$ & $\mathrm{n} / \mathrm{a}$ & $x x \%$ & $\mathrm{n} / \mathrm{a}$ & $x x \%$ & $\mathrm{n} / \mathrm{a}$ & $x x \%$ \\
\hline Subtotal & $16 \% \Delta$ & 214 & $100 \%$ & 293 & $100 \%$ & 303 & $100 \%$ & 314 & $100 \%$ \\
\hline NOT-DEGREE SEEKING & $-13 \% \Delta$ & 220 & & 229 & & 232 & & 240 & \\
\hline MEDICAL & $0 \% \Delta$ & n/a & & $\mathrm{n} / \mathrm{a}$ & & $\mathbf{n} / \mathbf{a}$ & & $\mathbf{n} / \mathbf{a}$ & \\
\hline TOTAL & $29 \% \Delta$ & 2269 & & 2449 & & 2529 & & 2616 & \\
\hline
\end{tabular}

Note*: AA transfers refer only to transfers from the Florida College System.

Planned Growth by Method of Instruction (for all E\&G students at all campuses)

\begin{tabular}{|c|c|c|c|c|c|c|c|c|c|}
\hline & \multirow{2}{*}{$\begin{array}{c}5 \text { YEAR } \\
\text { TREND } \\
(2006-07 \text { to } \\
2011-12) \\
\end{array}$} & \multicolumn{2}{|c|}{ 2011-12 } & \multicolumn{2}{|c|}{ 2013-14 } & \multicolumn{2}{|c|}{ 2014-15 } & \multicolumn{2}{|c|}{$2015-16$} \\
\hline & & $\begin{array}{l}\text { ACTUAL } \\
\text { FTE }\end{array}$ & $\begin{array}{c}\% \text { of } \\
\text { TOTAL }\end{array}$ & $\begin{array}{l}\text { PLANNED } \\
\text { FTE }\end{array}$ & $\begin{array}{l}\% \text { of } \\
\text { TOTAL }\end{array}$ & $\begin{array}{c}\text { PLANNED } \\
\text { FTE }\end{array}$ & $\begin{array}{c}\% \text { of } \\
\text { TOTAL }\end{array}$ & $\begin{array}{l}\text { PLANNED } \\
\text { FTE }\end{array}$ & $\begin{array}{l}\% \text { of } \\
\text { TOTAL }\end{array}$ \\
\hline \multicolumn{10}{|l|}{ UNDERGRADUATE } \\
\hline DISTANCE (>80\%) & $320 \% \Delta$ & 858 & $30 \%$ & 875 & $30 \%$ & 920 & $30 \%$ & 952 & $30 \%$ \\
\hline HYBRID (50\%-79\%) & $0 \% \Delta$ & 23 & $1 \%$ & 234 & $8 \%$ & 337 & $11 \%$ & 444 & $14 \%$ \\
\hline TRADITIONAL $(<50 \%)$ & $5 \% \Delta$ & 1941 & $69 \%$ & 1809 & $62 \%$ & 1808 & $59 \%$ & 1776 & $56 \%$ \\
\hline TOTAL & $38 \% \Delta$ & 2821 & $100 \%$ & 2961 & $100 \%$ & 3065 & $100 \%$ & 3172 & $100 \%$ \\
\hline \multicolumn{10}{|l|}{ GRADUATE } \\
\hline DISTANCE (80\%) & $320 \% \Delta$ & 87 & $33 \%$ & 72 & $26 \%$ & 75 & $26 \%$ & 78 & $26 \%$ \\
\hline HYBRID (50\%-79\%) & $0 \% \Delta$ & 2 & $1 \%$ & 14 & $5 \%$ & 23 & $8 \%$ & 33 & $11 \%$ \\
\hline TRADITIONAL (<50\%) & $-14 \% \Delta$ & 177 & $66 \%$ & 191 & $69 \%$ & 192 & $66 \%$ & 189 & $63 \%$ \\
\hline TOTAL & $18 \% \Delta$ & 267 & $100 \%$ & 280 & $100 \%$ & 290 & $100 \%$ & 300 & $100 \%$ \\
\hline
\end{tabular}

Note: Full-time Equivalent (FTE) student is a measure of instructional effort (and student activity) that is based on the number of credit hours that students enroll. FTE is based on the Florida definition, which divides undergraduate credit hours by 40 and graduate credit hours by 32 . Distance Learning is a course in which at least 80 percent of the direct instruction of the course is delivered using some form of technology when the student and instructor are separated by time or space, or both (per 1009.24(17), F.S.). Hybrid is a course where $50 \%$ to $79 \%$ of the instruction is delivered using some form of technology, when the student and instructor are separated by time or space, or both (per SUDS data element 2052). Traditional (and Technology Enhanced) refers to primarily face to face instruction utilizing some form of technology for delivery of supplemental course materials for no more than $49 \%$ of instruction (per SUDS data element 2052). 


\section{ENROLLMENT PLANNING (continued)}

Statutorily Required Enrollment Plan (Based on State-Fundable Florida FTE)

\begin{tabular}{|c|c|c|c|c|c|c|c|c|c|}
\hline & $\begin{array}{l}\text { Funded } \\
2012-13\end{array}$ & $\begin{array}{c}\text { Estimated } \\
\text { Actual } \\
2012-13\end{array}$ & $\begin{array}{l}\text { Funded } \\
\text { 2013-14 }\end{array}$ & $\begin{array}{c}1^{\text {st }} \text { Year } \\
\text { Estimated } \\
2013-14\end{array}$ & $\begin{array}{l}2^{\text {2d }} \text { Year } \\
\text { Planned } \\
2014-15\end{array}$ & $\begin{array}{c}3^{\text {rd }} \text { Year } \\
\text { Planned } \\
2015-16\end{array}$ & $\begin{array}{c}4^{\text {th }} \text { Year } \\
\text { Planned } \\
2016-17\end{array}$ & $\begin{array}{l}5^{\text {th }} \text { Year } \\
\text { Planned } \\
2017-18\end{array}$ & $\begin{array}{c}\text { 5-Year } \\
\text { Projected } \\
\text { Average } \\
\text { Annual } \\
\text { Growth } \\
\text { Rate }\end{array}$ \\
\hline \multicolumn{10}{|c|}{ Florida Resident } \\
\hline LOWER & 657 & 1071 & 657 & 1108 & 1147 & 1187 & 1230 & 1274 & $3.5 \%$ \\
\hline UPPER & 1486 & 1717 & 1486 & 1777 & 1839 & 1904 & 1970 & 2039 & $3.5 \%$ \\
\hline GRAD I & 227 & 264 & 227 & 273 & 283 & 293 & 302 & 312 & $3.5 \%$ \\
\hline GRAD II & $\mathrm{n} / \mathrm{a}$ & $\mathrm{n} / \mathrm{a}$ & $\mathrm{n} / \mathrm{a}$ & $\mathrm{n} / \mathrm{a}$ & $\mathrm{n} / \mathrm{a}$ & $\mathrm{n} / \mathrm{a}$ & $\mathrm{n} / \mathrm{a}$ & $\mathrm{n} / \mathrm{a}$ & $\mathrm{n} / \mathrm{a}$ \\
\hline TOTAL & 2370 & 3052 & 2370 & 3159 & 3269 & 3384 & 3502 & 3625 & $3.5 \%$ \\
\hline \multicolumn{10}{|c|}{ Non- Resident } \\
\hline LOWER & 0 & 33 & 0 & 34 & 41 & 44 & 45 & 46 & $3.5 \%$ \\
\hline UPPER & 0 & 40 & 0 & 41 & 38 & 40 & 41 & 42 & $3.5 \%$ \\
\hline GRAD I & 0 & 7 & 0 & 7 & 7 & 8 & 9 & 10 & $3.5 \%$ \\
\hline GRAD ॥ & 0 & $\mathrm{n} / \mathrm{a}$ & 0 & $\mathrm{n} / \mathrm{a}$ & $\mathrm{n} / \mathrm{a}$ & $\mathrm{n} / \mathrm{a}$ & $\mathrm{n} / \mathrm{a}$ & $\mathrm{n} / \mathrm{a}$ & $\mathrm{n} / \mathrm{a}$ \\
\hline TOTAL & 0 & 80 & 0 & 83 & 86 & 92 & 95 & 98 & $3.5 \%$ \\
\hline \multicolumn{10}{|l|}{ TOTAL } \\
\hline LOWER & 657 & 1104 & 657 & 1143 & 1188 & 1232 & 1275 & 1320 & $3.5 \%$ \\
\hline UPPER & 1486 & 1757 & 1486 & 1818 & 1877 & 1943 & 2011 & 2081 & $3.5 \%$ \\
\hline GRAD I & 227 & 271 & 227 & 228 & 290 & 301 & 311 & 322 & $3.5 \%$ \\
\hline GRAD II & 0 & $\mathrm{n} / \mathrm{a}$ & 0 & $\mathrm{n} / \mathrm{a}$ & $\mathrm{n} / \mathrm{a}$ & $\mathrm{n} / \mathrm{a}$ & $\mathrm{n} / \mathrm{a}$ & $\mathrm{n} / \mathrm{a}$ & $\mathrm{n} / \mathrm{a}$ \\
\hline TOTAL & 2370 & 3132 & 2370 & 3242 & 3355 & 3476 & 3598 & 3724 & $3.5 \%$ \\
\hline $\begin{array}{l}\text { TOTAL } \\
\text { (US FTE) }\end{array}$ & 3160 & 4175 & 3160 & 4321 & 4472 & 4629 & 4791 & 4959 & $3.5 \%$ \\
\hline
\end{tabular}

Medical Student Headcounts (FTE does not apply)

\section{Medical Doctorate}

\begin{tabular}{|c|c|c|c|c|c|c|c|c|c|}
\hline FLORIDA RESIDENT & $\mathrm{n} / \mathrm{a}$ & $n / a$ & $n / a$ & $n / a$ & $n / a$ & $n / a$ & $n / a$ & $n / a$ & $\%$ \\
\hline NON-RESIDENT & $\mathrm{n} / \mathrm{a}$ & $\mathrm{n} / \mathrm{a}$ & $\mathrm{n} / \mathrm{a}$ & $\mathrm{n} / \mathrm{a}$ & $\mathrm{n} / \mathrm{a}$ & $\mathrm{n} / \mathrm{a}$ & $\mathrm{n} / \mathrm{a}$ & $\mathrm{n} / \mathrm{a}$ & $\%$ \\
\hline TOTAL & $\mathrm{n} / \mathrm{a}$ & $\mathrm{n} / \mathrm{a}$ & $\mathrm{n} / \mathrm{a}$ & $\mathrm{n} / \mathrm{a}$ & n/a & n/a & n/a & $\mathrm{n} / \mathrm{a}$ & $\%$ \\
\hline Dentistry & $\mathrm{n} / \mathrm{a}$ & $\mathrm{n} / \mathrm{a}$ & $\mathrm{n} / \mathrm{a}$ & $\mathrm{n} / \mathrm{a}$ & $\mathrm{n} / \mathrm{a}$ & $\mathrm{n} / \mathrm{a}$ & $\mathrm{n} / \mathrm{a}$ & $\mathrm{n} / \mathrm{a}$ & \\
\hline FLORIDA RESIDENT & $n / a$ & $\mathrm{n} / \mathrm{a}$ & $\mathrm{n} / \mathrm{a}$ & $\mathrm{n} / \mathrm{a}$ & $\mathrm{n} / \mathrm{a}$ & $\mathrm{n} / \mathrm{a}$ & $\mathrm{n} / \mathrm{a}$ & $\mathrm{n} / \mathrm{a}$ & $\%$ \\
\hline NON-RESIDENT & $\mathrm{n} / \mathrm{a}$ & n/a & n/a & $\mathrm{n} / \mathrm{a}$ & $\mathrm{n} / \mathrm{a}$ & $\mathrm{n} / \mathrm{a}$ & n/a & $\mathrm{n} / \mathrm{a}$ & $\%$ \\
\hline TOTAL & $\mathrm{n} / \mathrm{a}$ & $\mathrm{n} / \mathrm{a}$ & $\mathrm{n} / \mathrm{a}$ & $\mathrm{n} / \mathrm{a}$ & $\mathrm{n} / \mathrm{a}$ & $\mathrm{n} / \mathrm{a}$ & $\mathrm{n} / \mathrm{a}$ & $\mathrm{n} / \mathrm{a}$ & $\%$ \\
\hline Veterinary & n/a & & & & & & & & \\
\hline FLORIDA RESIDENT & $\mathrm{n} / \mathrm{a}$ & $\mathrm{n} / \mathrm{a}$ & $\mathrm{n} / \mathrm{a}$ & $\mathrm{n} / \mathrm{a}$ & $\mathrm{n} / \mathrm{a}$ & $\mathrm{n} / \mathrm{a}$ & $\mathrm{n} / \mathrm{a}$ & $\mathrm{n} / \mathrm{a}$ & $\%$ \\
\hline NON-RESIDENT & $\mathrm{n} / \mathrm{a}$ & $\mathrm{n} / \mathrm{a}$ & $\mathrm{n} / \mathrm{a}$ & $\mathrm{n} / \mathrm{a}$ & n/a & $n / a$ & n/a & $\mathrm{n} / \mathrm{a}$ & $\%$ \\
\hline TOTAL & $\mathrm{n} / \mathrm{a}$ & $\mathrm{n} / \mathrm{a}$ & $\mathrm{n} / \mathrm{a}$ & $\mathrm{n} / \mathrm{a}$ & $\mathrm{n} / \mathrm{a}$ & $\mathrm{n} / \mathrm{a}$ & $\mathrm{n} / \mathrm{a}$ & $\mathrm{n} / \mathrm{a}$ & $\%$ \\
\hline Pharmacy & $\mathrm{n} / \mathrm{a}$ & & & & & & & & \\
\hline FLORIDA RESIDENT & $\mathrm{n} / \mathrm{a}$ & $\mathrm{n} / \mathrm{a}$ & $\mathrm{n} / \mathrm{a}$ & $\mathrm{n} / \mathrm{a}$ & $\mathrm{n} / \mathrm{a}$ & $\mathrm{n} / \mathrm{a}$ & $\mathrm{n} / \mathrm{a}$ & $\mathrm{n} / \mathrm{a}$ & $\%$ \\
\hline NON-RESIDENT & $n / a$ & $n / a$ & $\mathrm{n} / \mathrm{a}$ & $\mathrm{n} / \mathrm{a}$ & $n / a$ & $n / a$ & $\mathrm{n} / \mathrm{a}$ & $\mathrm{n} / \mathrm{a}$ & $\%$ \\
\hline TOTAL & $\mathrm{n} / \mathrm{a}$ & $\mathrm{n} / \mathrm{a}$ & n/a & $\mathrm{n} / \mathrm{a}$ & $\mathrm{n} / \mathrm{a}$ & $\mathrm{n} / \mathrm{a}$ & $\mathrm{n} / \mathrm{a}$ & $\mathrm{n} / \mathrm{a}$ & $\%$ \\
\hline
\end{tabular}




\section{ACADEMIC PROGRAM COORDINATION}

New Programs To Be Considered by University in 2013-14 for Implementation

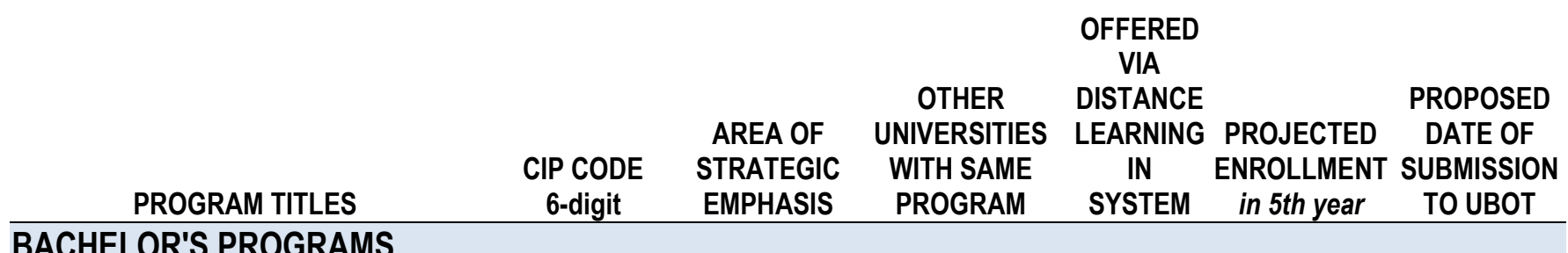

MASTER'S, SPECIALIST AND OTHER ADVANCED MASTER'S PROGRAMS

\begin{tabular}{|c|c|c|c|c|c|c|}
\hline Master of Accountancy & 52.0301 & No & $\begin{array}{l}\text { UF, FSU, FAU, } \\
\text { FIU, UCF, } \\
\text { UNF }\end{array}$ & No & 60 & $\begin{array}{c}\text { December } \\
2013\end{array}$ \\
\hline
\end{tabular}

DOCTORAL PROGRAMS

New Programs To Be Considered by University in 2014-16 for Implementation

\begin{tabular}{|c|c|c|c|c|c|c|}
\hline PROGRAM TITLES & $\begin{array}{c}\text { CIP CODE } \\
\text { 6-digit }\end{array}$ & $\begin{array}{c}\text { AREA OF } \\
\text { STRATEGIC } \\
\text { EMPHASIS }\end{array}$ & $\begin{array}{c}\text { OTHER } \\
\text { UNIVERSITIES } \\
\text { WITH SAME } \\
\text { PROGRAM }\end{array}$ & $\begin{array}{c}\text { OFFERED } \\
\text { VIA } \\
\text { DISTANCE } \\
\text { LEARNING } \\
\text { IN SYSTEM }\end{array}$ & $\begin{array}{l}\text { PROJECTED } \\
\text { ENROLLMEN } \\
\text { in 5th year }\end{array}$ & $\begin{array}{l}\text { PROPOSED } \\
\text { DATE OF } \\
\text { SUBMISSION } \\
\text { TO UBOT }\end{array}$ \\
\hline \multicolumn{7}{|l|}{ BACHELOR'S PROGRAMS } \\
\hline B.S. Marine Science & $\begin{array}{c}40.0607 \text { or } \\
26.1302\end{array}$ & STEM & FIU, UWF & No & 50 & March 2015 \\
\hline
\end{tabular}

\section{MASTER'S, SPECIALIST AND OTHER ADVANCED MASTER'S PROGRAMS}

\begin{tabular}{lcccccc}
\hline Non-Profit Leadership and Management & 52.0206 & No & $\begin{array}{c}\text { FAU, UCF, } \\
\text { UWF }\end{array}$ & Partial & 30 & March 2015 \\
$\begin{array}{l}\text { Education Specialist (Special } \\
\text { Ed/ESOL) }\end{array}$ & 13.1001 & Education & FSU, UF & Partial & 30 & March 2016
\end{tabular}




\section{KEY PERFORMANCE INDICATOR DEFINITIONS}

\section{Goals Common to All Universities \\ Academic Quality \\ National Ranking for University and Program(s)}

Avg. SAT Score (for 3 subtests)

\section{Avg. HS GPA}

\section{Professional/Licensure Exam \\ First-time Pass Rates}

Exams Above National/State Benchmark

Exams Below National/State Benchmark

\section{Percent of Undergraduate Seniors Participating in a Research Course}

\section{Operational Efficiency}

\section{Freshman Retention Rate}

\section{FTIC Graduation Rates}

In 4 years (or less)

In 6 years (or less)

\section{AA Transfer Graduation Rates \\ In 2 years (or less) \\ In 4 years (or less)}

\section{Percent of Bachelor's Degrees Without Excess Hours}

\section{Average Time to Degree (for FTIC)}

Describe plans for increasing national preeminence of University and select programs.

The average SAT score for all three subtests (reading, mathematics and writing) for Admitted \& Registered FTIC (B,E) students (Fall only).

The average HS GPA for Admitted \& Registered FTIC and early admit $(B, E)$ students. Max score is 5.0 .

The number of exams with first-time pass rates above and below the national or state average, as reported in the 2011-12 Accountability report, including: Nursing, Law, Medicine (3 subtests), Veterinary, Pharmacy, Dental (2 subtests), Physical Therapy, and Occupational Therapy.

This metric represents the percentage of seniors who enrolled in a Research course during their last year. Board staff will work with University officials during the summer of 2013 to determine a systemwide definition of 'a research course'.

The percentage of a full-time, first-time-in-college (FTIC) undergraduate cohort (entering in fall term or summer continuing to fall) that is still enrolled or has graduated from the same institution in the following fall term as reported in the 2011-12 Accountability report (table 4B) - see link.

As reported in the 2011-12 Accountability report (table 4D), Firsttime-in-college (FTIC) cohort is defined as undergraduates entering in fall term (or summer continuing to fall) with fewer than 12 hours earned since high school graduation. The rate is the percentage of the initial cohort that has either graduated from or is still enrolled in the same institution by the fourth or sixth academic year. Both fulltime and part-time students are used in the calculation. The initial cohort is revised to remove students, who have allowable exclusions as defined by IPEDS, from the cohort.

As reported in the 2011-12 Accountability report (table 4E), AA Transfer cohort is defined as undergraduates entering in the fall term (or summer continuing to fall) and having earned an AA degree from an institution in the Florida College System. The rate is the percentage of the initial cohort that has either graduated from or is still enrolled in the same institution by the second or fourth academic year. Both full-time and part-time students are used in the calculation. The initial cohort is revised to remove students, who have allowable exclusions as defined by IPEDS, from the cohort. As reported in the 2011-12 Accountability report (table 4J), the percentage of baccalaureate degrees awarded within $110 \%$ of the hours required for a degree. This metric computes total academic credit (minus exemptions per 1009.286, F.S.) as a percentage of catalog hours required for the students major.

This metric is the number of years between the start date (using the student's entry date) and the end date (using the last month in the term degree was granted) for a graduating class of first-time, singlemajor baccalaureates in 120 credit hour programs within a (Summer, Fall, Spring) year. The student type is based on student type at time of entry. 
Return on Investment

Bachelor's Degrees Awarded

Percent of Bachelor's Degrees in STEM

Graduate Degrees Awarded

Percent of Graduate Degrees in STEM

Percent of Baccalaureate Graduates Employed in Florida

Percent of Baccalaureate Graduates Continuing their Education (in FL)

Annual Gifts Received (\$M)

Endowment (\$M)

Goals Specific to Research Universities

Academic Quality

Faculty Awards

National Academy Members

Number of Post-Doctoral appointees
This is a count of baccalaureate degrees awarded as reported in the 2011-12 Accountability Report (table 4G) - see link.

The percentage of baccalaureate degrees that are classified as STEM by the Board of Governors in the SUS program inventory as reported in the 2011-12 Accountability Report (table 4H) - see link. This is a count of graduate degrees awarded as reported in the 2011-12 Accountability Report (table 5B) - see link.

The percentage of baccalaureate degrees that are classified as STEM by the Board of Governors in the SUS program inventory as reported in the 2011-12 Accountability Report (table 5C) - see link. This is the percentage of baccalaureate graduates with valid social security numbers that are employed in Florida during the Oct-Dec fiscal quarter based on FETPIP data - see link.

This is the percentage of baccalaureate graduates with valid social security numbers that are continuing their education in Florida during the Oct-Dec fiscal quarter based on FETPIP data - see link. As reported in the Council for Aid to Education's Voluntary Support of Education (VSE) survey in the section entitled "Gift Income Summary," this is the sum of the present value of all gifts (including outright and deferred gifts) received for any purpose and from all sources during the fiscal year, excluding pledges and bequests. (There's a deferred gift calculator at www.cae.org/vse.) The present value of non-cash gifts is defined as the tax deduction to the donor as allowed by the IRS.

Endowment value at the end of the fiscal year, as reported in the annual NACUBO Endowment Study (changed to the NACUBOCommon Fund Study of Endowments in 2009).

Awards include: American Council of Learned Societies (ACLS)

Fellows, Beckman Young Investigators, Burroughs Wellcome Fund

Career Awards, Cottrell Scholars, Fulbright American Scholars, Getty

Scholars in Residence, Guggenheim Fellows, Howard Hughes

Medical Institute Investigators, Lasker Medical Research Awards, MacArthur Foundation Fellows, Andrew W. Mellon Foundation Distinguished Achievement Awards, National Endowment for the Humanities (NEH) Fellows, National Humanities Center Fellows, National Institutes of Health (NIH) MERIT, National Medal of Science and National Medal of Technology, NSF CAREER awards (excluding those who are also PECASE winners), Newberry Library Long-term Fellows, Pew Scholars in Biomedicine, Presidential Early Career Awards for Scientists and Engineers (PECASE), Robert Wood Johnson Policy Fellows, Searle Scholars, Sloan Research Fellows, Woodrow Wilson Fellows. As reported by the Top American Research Universities - see link.

The number of National Academy members included in the National Academy of Sciences, National Academy of Engineering, and the Institute of Medicine. As reported by the Top American Research Universities - see link. As submitted to the National Science Foundation Survey of Graduate Students and Postdoctorates in Science \& Engineering (also known as the GSS) - see link. 


\section{Number of Science \& Engineering Disciplines nationally ranked in Top 100 for research expenditures}

\section{Return on Investment}

Total Research Expenditures (\$M)

Science \& Engineering Research Expenditures in non-medical/health sciences

\section{Percent of R\&D Expenditures} funded from External Sources

Patents Issued

Licenses/Options Executed

Licensing Income Received (\$M)
The number of Science \& Engineering disciplines the university ranks in the top 100 (for public and private universities) based on the National Science Foundation's annual survey for R\&D expenditures, which identifies 8 broad disciplines within Science \& Engineering (Computer Science, Engineering, Environmental Science, Life Science, Mathematical Sciences, Physical Sciences, Psychology, and Social Sciences). Historically NSF provided these rankings (see tables $45-61$ at link), but now data must be queried via WebCASPAR - see link.

Total expenditures for all research activities (including non-science and engineering activities) as reported on the NSF annual survey and the 2011-12 Accountability Report - see link. This metric reports the Science \& Engineering total R\&D expenditures minus the research expenditures for medical sciences as reported by the National Science Foundation. Historically NSF provided these data (see link, table 36 minus table 52), but now data must be queried via WebCASPAR - see link.

The percentage of total R\&D expenditures that come from Federal, Private Industry and Other sources (does not include State or Institutional funds) as reported in the 2011-12 Accountability Report (table 6A) - see link.

The number of patents issued in the fiscal year as reported in the 2011-12 Accountability Report (table 6A) - see link.

Licenses/options executed in the fiscal year for all technologies as reported in the 2011-12 Accountability Report (table 6A) - see link. License issue fees, payments under options, annual minimums, running royalties, termination payments, amount of equity received when cashed-in, and software and biological material end-user license fees of $\$ 1,000$ or more, but not research funding, patent expense reimbursement, valuation of equity not cashed-in, software and biological material end-user license fees of less than $\$ 1,000$, or trademark licensing royalties from university insignia. Data as reported in the 2011-12 Accountability Report (table 6A) - see link. The number of start-up companies that were dependent upon the licensing of University technology for initiation as reported in the 2011-12 Accountability Report (table 6A) - see link.

This metric compares the overall national university ranking to the financial resources rank as reported by the US News and World report.

The number of research doctoral degrees awarded annually as reported in the 2011-12 Accountability Report (table 5B) - see link

The number of professional doctoral degrees awarded annually as reported in the 2011-12 Accountability Report (table 5B) - see link 